\title{
MODEL PRODUKSI BIOETANOL DARI LIMBAH KEJU MENGGUNAKAN KLUYVEROMYCES MARXIANUS
}

\author{
Rudy Agustriyanto, Akbarningrum Fatmawati \\ Jurusan Teknik Kimia, Fakultas Teknik, Universitas Surabaya \\ Jl. Raya Kalirungkut, Surabaya, 60292, Indonesia \\ Email: rudy.agustriyanto@staff.ubaya.ac.id.
}

\begin{abstract}
Abstrak
Menipisnya cadangan minyak bumi telah meningkatkan minat pengembangan sumber energi alternatif terbarukan. Limbah keju yang biasa disebut whey adalah salah satu bahan baku yang dapat digunakan untuk produksi bioetanol. Tujuan penelitian ini adalah melakukan kajian kritis terhadap proses fermentasi limbah keju dengan mengaplikasikan konsep dasar keteknikan dan matematika, mempelajari karakteristik proses fermentasi limbah keju menjadi bioetanol, dan mencari desain fermenter yang optimum. Hal ini dilakukan dengan membuat model sistem steady state dari fermentasi limbah keju menjadi etanol berdasarkan data kinetika dari peneliti terdahulu dan dengan menggunakan prinsip fundamental neraca massa. Model tersebut kemudian digunakan untuk mensimulasikan fermentasi limbah keju secara kontinyu untuk produksi etanol. Pada kondisi steady state, proses fermentasi limbah keju menjadi bioetanol dipengaruhi oleh hydraulic retention time $(R)$. Pada kondisi steady state tersebut diperoleh harga R optimum sebesar 25 jam didasarkan pada produktifitas etanol yang tinggi. Hasil penelitian ini akan bermanfaat dalam perancangan proses dan pengendalian reaksi fermentasi limbah keju menjadi etanol. Pemanfaatan limbah keju yang masih mengandung gula sehingga dapat difermentasi akan memberikan nilai tambah pada limbah tersebut disamping memberikan alternatif sumber energi terbarukan yang sangat dibutuhkan oleh karena krisis energi.
\end{abstract}

Kata kunci: Pemodelan, proses produksi, bioetanol, simulasi

\begin{abstract}
The depletion of oil reserves has been increasing interest in the development of alternative renewable energy sources. Cheese whey as a waste of cheese production is one of the raw materials that can be used for bioethanol production. The aim of this study is to conduct critical assessment of the cheese whey fermentation process by applying the basic concepts of engineering and mathematics, to investigate the characteristics of the cheese whey fermentation process into bioethanol, and to obtain the optimum design of fermenter. This is done by developing steady state model of cheese whey fermentation system into ethanol based on kinetic data from previous research and using mass balance principle. The model was then used to simulate the continuous fermentation of cheese whey for ethanol production. At steady state conditions, the fermentation process of cheese whey into bioethanol is affected by the hydraulic retention time $(R)$. At steady state conditions, the optimum value of $R$ obtained is 25 hours based on high ethanol productivity. The results of this study will be useful in the design process and control of cheese whey fermentation reactions into ethanol. The utilization of waste from cheese production (cheese whey) that contain sugars which can be fermented will provide added value to the waste while providing an alternative source of renewable energy that is needed due to energy crisis.
\end{abstract}

Keywords: Modeling, production process, bioethanol, simulation

\section{Pendahuluan}

Menipisnya cadangan minyak bumi telah meningkatkan minat pengembangan sumber energi alternatif terbarukan. Limbah keju adalah salah satu bahan baku yang dapat digunakan untuk produksi bioetanol. Pada umumnya limbah keju mengandung 5-6\% laktosa, 0.8-1\% protein, dan $0.06 \%$ lemak [5].

Oleh karena adanya ketergantungan pada luar negeri dalam teknologi proses bioetanol skala besar (20 ribu ton/tahun), maka diperlukan pengembangan teknologi proses yang kompetitif dan efektif untuk mengkonversi gula atau pati menjadi bioetanol. Penelitian ini sangat relevan untuk pengembangan teknologi industri proses yang kompetitif dan efektif.

Whey adalah istilah yang digunakan untuk limbah keju. Whey atau plasma susu tersebut merupakan cairan sisa yang didapat setelah susu digumpalkan. Whey dapat dimanfaatkan sebagai bahan aditif dalam banyak proses pembuatan makanan, antara lain dalam pembuatan roti, biskuit, dan pastry komersial. Pemanfaatan whey sebagai bahan baku pembuatan etanol memberi nilai tambah bagi bahan tersebut, karena biasanya bahan tersebut dianggap sebagai limbah. Pembuatan etanol dapat dilakukan dengan proses fermentasi.

Beberapa peneliti telah mempelajari penggunaan limbah keju untuk difermentasi menjadi etanol $[3,4,5,7]$. Fermentasi etanol dari whey yang telah dilakukan menggunakan yeast Kluyveromyces marxianus NRRL1195 [5], Kluyveromyces marxianus MTCC 1288 [7], dan Candida pseudotropicalis ATCC 8619 [3, 4]. Kargi dan Ozmihci (2006) mempelajari pengaruh parameter operasi pada fermentasi limbah keju menjadi etanol. Sedangkan Ghaly dan Taweel mempelajari kinetika pertumbuhan dan 
produksi etanol dari whey secara batch dan kontinyu [3, 4].

Model matematika kondisi steady state fermentasi limbah keju menjadi etanol dalam penelitian ini berguna dalam aspek perancangan proses produksi bioetanol. Konversi yang optimum dalam fermenter dapat diperoleh atau diperkirakan berdasarkan model tersebut.

\section{Teori}

Fermentasi mikrobial adalah suatu proses dimana populasi mikroorganisme (bakteri, ragi, kapang, dll) ditumbuhkan dengan menggunakan elemen nutrisi tertentu (nutrients) pada kondisi lingkungan yang menguntungkan (suhu, $\mathrm{pH}$, pengadukan, aerasi, dll). Fermentasi tersebut merupakan transformasi material (umumnya substrat yang mengandung karbon,) menjadi produk hasil dari aktifitas metabolisme sel [1].

Komponen utama dari reaksi fermentasi adalah:

- Substrat (S) diperlukan untuk pertumbuhan mikroorganisme, biasanya mengandung karbon (glukosa, etanol, dll) dan nitrogen $\left(\mathrm{NO}_{3}, \mathrm{NH}_{4}\right.$, dll) dan fosfor $\left(\mathrm{PO}_{4}\right.$, dll).

- Biomassa mikroba (X)

- Produk akhir (P) untuk makanan hasil pertanian (minyak, bir, keju, wine, dll), bahan kimia (pelarut, enzim, asam amino, dll), industri farmasi (antibiotik, hormon, vitamin dll) atau untuk menghasilkan energi (etanol, biogas, dll).

Dalam produksi, bioreaktor dapat dioperasikan secara batch, semikontinyu dan kontinyu. Dalam operasi batch, semua elemen nutrisi yang diperlukan untuk pertumbuhan biologis dimasukkan pada awal reaksi, tidak ada suplai ataupun pengeluaran bahan sesudahnya, kecuali untuk pengambilan sampel pengukuran. Reaksi juga berlangsung pada volume konstan. Satu-satunya kegiatan operator adalah yang terkait dengan variabel lingkungan (pH, suhu, kecepatan pengadukan, aerasi, dll). Sehingga, hanya sedikit alat yang diperlukan dalam implementasinya. Hal inilah yang menarik bagi industri. Keuntungan lainnya adalah jaminan kemurnian biakan karena resiko kontaminasi yang kecil. Kerugiannya adalah kesulitan dalam mengoptimalkan penggunaan mikroorganisme dan inhibisi substrat karena tingginya konsentrasi awal yang dapat memperpanjang waktu proses dan membatasi beban substrat awal. Pada mode operasi semi kontinyu terdapat suplai elemen nutrisi bila dibutuhkan oleh mikroorganisme. Hal ini memungkinkan untuk menghilangkan masalah inhibisi dan beroperasi pada laju pertumbuhan spesifik yang mendekati maksimum. Mode operasi kontinyu digunakan secara luas pada pengolahan air secara biologis. Operasi kontinyu bekerja pada kondisi steady state dan suplai yang tetap dengan mempertahankan sistem pada keadaan stasioner dan menghindari fenomena inhibisi karena adanya efek pengenceran dari suplai. Pada operasi ini dapat dihasilkan produksi yang tinggi dengan ukuran reaktor yang kecil.

Dalam perancangan dan interpretasi unjuk kerja reaktor biologi, diperlukan informasi fisis dan biologis. Faktor fisis yang mempengaruhi lingkungan umum hidrodinamis pada suatu bioreaktor meliputi beberapa paramter seperti pola aliran liquida dan waktu sirkulasi, efisiensi distribusi udara dan holdup gas, laju perpindahan massa oksigen, intensitas pencampuran dan pengaruh geseran (shear). Faktor-faktor tersebut dipengaruhi oleh geometri bioreaktor dan pengaduk (kecepatan pengaduk, efek baffle) dan oleh pengaruh sifat fisis seperti viskositas cairan dan tegangan permukaan. Semuanya dapat berpengaruh pada ukuran gelembung dan hidrodinamika cairan dan gas. Input biokinetika melibatkan beberapa faktor seperti laju pertumbuhan sel, produktifitas sel dan laju konsumsi substrat. Seringkali informasi ini diperoleh dari data laboratorium, didapatkan pada kondisi tertentu yang sering sekali jauh dari kondisi nyata pada reaktor skala besar.

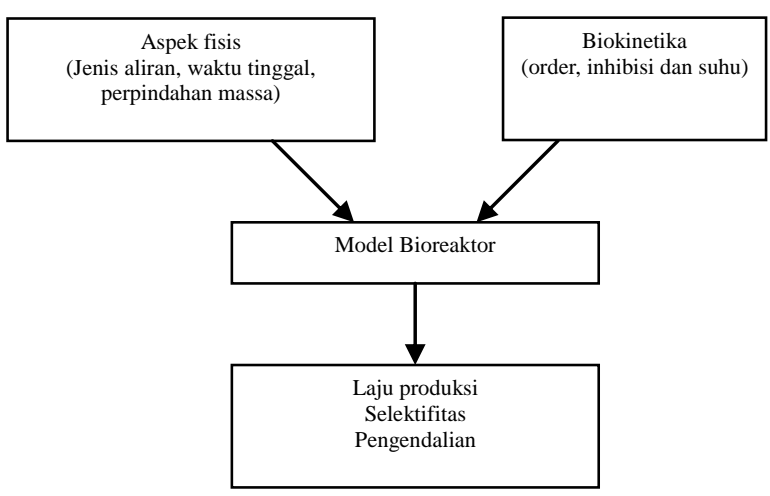

Gambar 1. Informasi untuk Pemodelan Bioreaktor [2]

Meskipun merupakan input yang berbeda seperti yang ditunjukan pada Gambar 1., pada kenyataannya terdapat interaksi yang perlu diperhitungkan diantara kondisi hidrodinamik bioreaktor dan biokinetika sel, morfologi dan fisiologi, dan salah satu seni pemodelan adalah melibatkan secara komprehensif pengaruh faktorfaktor tersebut. Oleh sebab itu pada bioreaktor skala besar, beberapa sel mungkin mengalami kekurangan nutrisi esensial karena kombinasi waktu sirkulasi yang lama dan laju suplai nutrisi yang tidak memadai. Hal ini disebabkan oleh pencampuran yang tidak memadai atau perpindaham massa yang tidak efisien. Pengadukan dan pengaruh geseran (shear) dapat berdampak pada morfologi sel sehingga mempengaruhi viskositas liquida, yang pada akhirnya berpengaruh pada bervariasinya densitas sel. Hal ini berarti bahwa proses pertumbuhan sel mempengaruhi hidrodinamika bioreaktor secara komplek dan interaktif. Perubahan pada fisiologi sel sedemikian hingga proses pertumbuhan sel bergeser dari produksi sel lebih lanjut menjadi produksi metabolit sekunder dapat juga dipengaruhi oleh keterbatasan jumlah dan laju suplai nutrien esensial pada media secara selektif. Perubahan fisiologi sel ini dapat dipengaruhi oleh hidrodinamika bioreaktor dan juga oleh cara operasi bioreaktor tersebut.

Semua permasalahan itu sangat kompleks tetapi seperti terlihat pada Gambar 1, ketika semua informasi dikombinasikan pada model bioreaktor yang realistis dan 
benar, akan diperoleh hasil yang memuaskan dan dapat digunakan untuk menentukan laju produksi sel, produk, selektifitas produk, pengendalian dan optimisasi proses dengan meyakinkan [2].

Dalam fermentasi secara batch, pertumbuhan sel mikroorganisme terdiri dari beberapa fase yang ditunjukkan seperti pada Gambar 2 dimana karakteristik masing-masing fase ditunjukkan pada Tabel 1.

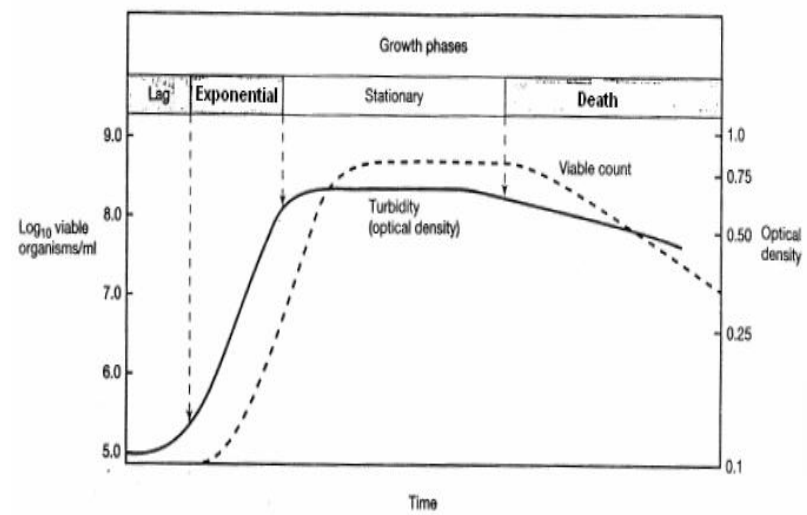

Gambar 2. Kurva pertumbuhan mikroorganisme sistem batch

Tabel 1. Karakteristik Fase-Fase Pertumbuhan Sel

\begin{tabular}{|l|l|l|}
\hline $\begin{array}{l}\text { Fase } \\
\text { pertumbuhan }\end{array}$ & Laju & Karakteristik \\
\hline Lag & Nol & $\begin{array}{l}\text { Tidak terdapat } \\
\text { peningkatan jumlah sel, } \\
\text { ukuran sel bertambah. } \\
\text { Sel aktif secara fisiologis } \\
\text { dan mensintesa enzim- } \\
\text { enzim baru untuk adaptasi }\end{array}$ \\
\hline Eksponensial & $\begin{array}{l}\text { Maksimal } \\
\text { dan } \\
\text { konstan }\end{array}$ & $\begin{array}{l}\text { Kondisi balanced growth } \\
\text { dimana sel hampir } \\
\text { seragam dalam komposisi } \\
\text { kimia dan aktifitas } \\
\text { fisiologisnya. }\end{array}$ \\
\hline Stasioner & Nol & $\begin{array}{l}\text { Akumulasi produk } \\
\text { metabolisme yang toksik } \\
\text { dan kehabisan nutrien } \\
\text { pertumbuhan }\end{array}$ \\
\hline Kematian & Negatif & $\begin{array}{l}\text { Terjadi akumulasi zat } \\
\text { toksik dan penurunan } \\
\text { nutrien lebih lanjut }\end{array}$ \\
\hline
\end{tabular}

Pada fase eksponensial, pertumbuhan secara matematis dapat dimodelkan melalui persamaan berikut:

$\frac{d X}{d t}=\mu X$

Dimana:

$X=$ konsentrasi sel, $\mathrm{g} / \mathrm{L}$

$\mathrm{t} \quad=$ waktu, jam $\mu=$ laju pertumbuhan spesifik, $\mathrm{jam}^{-1}$

Model kinetika pertumbuhan sel terbagi menjadi model terstruktur dan tak terstruktur. Model tak terstruktur menganggap sel sebagai satu unit yang berinteraksi dengan lingkungannya sehingga pertumbuhannya dapat diwakili oleh salah satu komponen saja. Beberapa model tak terstruktur yang menjelaskan limitasi substrate pada pertumbuhan sel adalah model Monod, Contois, Blackman, Tessier dan Moser.

Hubungan antara laju pertumbuhan spesifik dan konsentrasi substrat pada model Monod adalah:

$\mu=\frac{\mu_{m} S}{K s+S}$

Dimana:

$\mu_{\mathrm{m}} \quad=$ laju pertumbuhan spesifik maksimum, $\mathrm{jam}^{-1}$

$S \quad=$ konsentrasi substrat, $\mathrm{g} / \mathrm{L}$

Ks = saturation constant, $\mathrm{g} / \mathrm{L}$

Kargi dan Ozmichi (2007) telah memodelkan pertumbuhan sel Kluyveromyces marxianus (DSMZ 7239) pada bubuk limbah keju (cheese whey powder) menggunakan model Monod tersebut. Penggunaan model tersebut pada fermentasi limbah keju oleh Kluyveromyces marxianus tersebut berarti mengabaikan pengaruh inhisi substrat dan etanol pada pertumbuhan yeast tersebut.

Menurut Ghaly dan Taweel (1997), model fermentasi etanol melibatkan inhibisi etanol sebagai produk dan substrat karena konsentrasi produk dan substrat yang tinggi dapat menghambat pertumbuhan. Oleh sebab itu, laju pertumbuhan spesifik harus melibatkan inbisi substrat dan produk tersebut. Hubungan antara Laju pertumbuhan spesifik dan inhibisi substrat dan produk adalah sebagai berikut:

$\mu=\frac{\mu_{m} S}{K s+S} \frac{K_{p}}{K_{p}+P} \frac{K_{s}{ }^{\prime}}{K_{s}{ }^{\prime}+S}$

Dimana:

$K_{p}=$ konsentrasi etanol yang menghambat, $\mathrm{g} / \mathrm{L}$

$P \quad=$ konsentrasi produk (etanol), $\mathrm{g} / \mathrm{L}$

$K_{s}^{\prime}=$ konsentrasi substrat dimana pertumbuhan terhambat, $\mathrm{g} / \mathrm{L}$

Beberapa parameter yang terkait dengan stoikiometeri reaksi fermentasi telah didefinisikan untuk mempermudah dalam mengembangkan model kinetika. Yield pertumbuhan sel dan pembentukan produk terhadap substrat dalam fermentasi didefinisikan sebagai berikut: 
$Y_{X / S}=-\frac{\Delta X}{\Delta S}$

$Y_{P / S}=-\frac{\Delta P}{\Delta S}$

Dimana:

$Y_{X / S}=$ yield sel terhadap substrat, $\mathrm{g} / \mathrm{g}$

$\Delta X=$ perubahan konsentrasi sel, $\mathrm{g} / \mathrm{L}$

$\Delta S=$ perubahan konsentrasi substrat, $\mathrm{g} / \mathrm{L}$

$Y_{P / S}=$ yield produk terhadap substrat, $\mathrm{g} / \mathrm{g}$

$\Delta P=$ perubahan konsentrasi produk, $\mathrm{g} / \mathrm{L}$

Produk yang dihasilkan oleh mikroorganisme dalam reaksi fermentasi dapat diklasifikasikan sebagai berikut:

1. Produk yang berkaitan dengan pertubuhan yaitu produk yang secara simultan dengan pertumbuhan dihasilkan oleh mikroorganisme. Pembentukan produk seperti ini dapat dimodelkan sebagai berikut:

$q_{p}=\frac{1}{X} \frac{d P}{d t}=\alpha \mu$

Dimana:

$q_{p}=$ laju pembentukan produk spesifik, g/L.jam

$\alpha=$ konstanta produk pertumbuhan

2. Produk yang tidak berkaitan dengan pertumbuhan yaitu produk yang dihasilkan pada fase stasioner. Produk seperti ini dapat dimodelkan sebagai berikut:

$$
q_{p}=\beta
$$

Dimana:

$\beta=$ konstanta produk non pertumbuhan

3. Produk campuran dengan model:

$$
q_{p}=\alpha \mu+\beta
$$

\section{Metodologi Penelitian}

\section{Tahapan Penelitian}

Tahapan yang dilakukan dalam penelitian ini adalah sebagai berikut:

a. Studi literatur b. Pemodelan sistem steady state fermentasi limbah keju menjadi etanol berdasarkan data kinetika dari peneliti terdahulu dan dengan menggunakan prinsip fundamental neraca massa.

c. Pembuatan program simulasi fermentasi limbah keju menjadi etanol dengan menggunakan Matlab dan Simulink. d. Simulasi fermentasi limbah keju menjadi etanol steady state

\section{Pemodelan Sistem Steady State Fermentasi Limbah keju}

Kargi dan Ozmichi (2007) memodelkan fermentasi limbah keju menjadi etanol dengan menggunakan model Monod seperti yang dituliskan pada persamaan (2). Skema fermenter yang digunakan pada sistem kontinyu ditunjukkan pada Gambar 3.

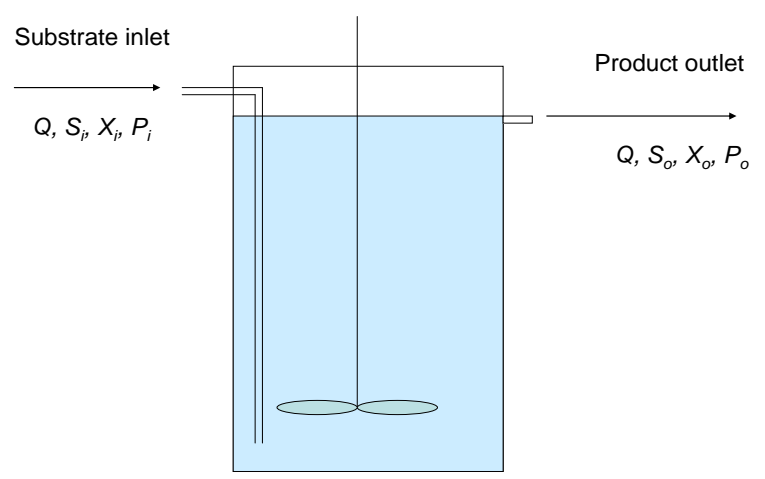

\section{Gambar 3. Skema fermentasi limbah keju secara kontinyu}

Pada sistem kontinyu, fermentasi dapat dimodelkan yang diperoleh dari persamaan neraca massa komponen yang ada di dalam fermenter. Persamaan neraca massa tersebut adalah sebagai berikut:

1. Neraca massa sel:

$[$ Laju akumulasisel $]=[$ Laju sel masuk $]+$

$$
\begin{aligned}
& \text { [Laju pertumbuhan sel]- } \\
& {[\text { Laju kematian sel] }-} \\
& {[\text { Laju keluar sel }]}
\end{aligned}
$$$$
V \frac{d X}{d t}=Q X_{i}+\mu X V-K_{d} X V-Q X
$$$$
\frac{d X}{d t}=\frac{Q}{V} X_{i}+\mu X-K_{d} X-\frac{Q}{V} X
$$

Pada kondisi steady state laju akumulasi akan sama dengan nol atau $\frac{d X}{d t}=0$. Dengan asumsi bahwa aliran masuk tidak mengandung mikroorganisme (steril) atau $X_{i}=0$, maka persamaan di atas akan menjadi:

$0=\frac{\mu_{m} S}{K_{s}+S} X-K_{d} X-\frac{Q}{V} X$ 
Waktu tinggal dalam reaktor atau hydraulic retention time (HRT) didefinisikan sebagai berikut:

$$
R=\frac{V}{Q}
$$

Sehingga persamaan neraca massa steady state sebagai fungsi dari HRT adalah sebagai berikut:

$$
0=\frac{\mu_{m} S}{K_{s}+S}-K_{d}-\frac{1}{R}
$$

2. Neraca massa substrat:

[Laju akumulasisubstrat $]=[$ Laju substrat masuk $]-$

[Laju konsumsisubstrat untuk pertumbuha] -

[Laju substrat untuk maintenance]-

[Laju substratuntuk pembentukan produk]-

[Laju substratkeluar]

$\frac{d S}{d t} V=Q S_{i}-\left(R_{S X}+R_{S m}+R_{S P}\right) V-Q S$

$\frac{d S}{d t}=\frac{Q}{V} S_{i}-$

$$
\left(\frac{\mu_{m} S}{K_{s}+S} \frac{X}{Y_{X / S}}+m_{s} X+\frac{\alpha \mu_{m} S}{K_{s}+S} \frac{X}{Y_{P / S}}\right)-
$$

$$
\frac{Q}{V} S
$$

$$
\begin{aligned}
\frac{d S}{d t}= & \frac{1}{R} S_{i}- \\
& \left(\frac{\mu_{m} S}{K_{s}+S} \frac{X}{Y_{X / S}}+m_{s} X+\frac{\alpha \mu_{m} S}{K_{s}+S} \frac{X}{Y_{P / S}}\right)- \\
& \frac{1}{R} S
\end{aligned}
$$

Pada kondisi steady-state persamaan di atas akan menjadi:

$$
\begin{aligned}
0= & \frac{1}{R} S_{i}- \\
& \left(\frac{\mu_{m} S}{K_{s}+S} \frac{X}{Y_{X / S}}+m_{s} X+\frac{\alpha \mu_{m} S}{K_{s}+S} \frac{X}{Y_{P / S}}\right)- \\
& \frac{1}{R} S
\end{aligned}
$$

3. Neraca massa Produk:
[Laju akumulasi produk etanol $]=$

$$
\begin{aligned}
& \text { [Laju etanol masuk]+} \\
& \text { [Laju produksi etanol]- } \\
& \text { [Laju etanol keluar] }
\end{aligned}
$$

$\frac{d P}{d t}=\frac{1}{R} P_{i}+\left[\frac{\alpha \mu_{m} S X}{K_{s}+S}+\beta X\right]-\frac{1}{R} P$

Pada kondisi steady state persamaan di atas menjadi:

$0=\frac{1}{R} P_{i}+\left[\frac{\alpha \mu_{m} S X}{K_{S}+S}+\beta X\right]-\frac{1}{R} P$

Produktifitas dari sebuah fermenter kontinyu untuk produk dan sel dapat ditentukan melalui persaman berikut:

$P d_{\text {sel }}=X / R$
$P d_{\text {produk }}=P / R$

Dimana:

$P d_{\text {sel }}=$ produktifitas sel, g/L.jam

$P d_{\text {produk }}=$ produktifitas produk, $\mathrm{g} / \mathrm{L} . \mathrm{h}$

\section{Simulasi Fermentasi Steady State Limbah Keju}

Dari model yang diturunkan untuk sistem steady state, model akan diselesaikan secara numerik dengan bantuan komputer (software Matlab). Akan dipelajari kelakuan steady state fermentasi limbah keju yaitu konsentrasi sel, substrat dan produk terhadap variasi hydraulic retention time (HRT).

Hasil

Data kinetika untuk fermentasi limbah keju oleh Kluyveromyces marxianus (DSMZ 7239) ditunjukkan pada Tabel 2 [6].

Tabel 2. Parameter Kinetika

\begin{tabular}{|c|c|l|}
\hline Parameter & \multicolumn{2}{|c|}{ Harga } \\
\hline$\mu_{m}$ & 0,094 & jam \\
\hline$K_{s}$ & 78,5 & $\mathrm{~g} / \mathrm{L}$ \\
\hline$Y_{X / S}$ & 0,2 & $\mathrm{~g} / \mathrm{g}$ \\
\hline$Y_{P / S}$ & 0,42 & $\mathrm{~g} / \mathrm{g}$ \\
\hline$\alpha$ & 3,16 & \\
\hline
\end{tabular}


Model matematika dari fermentasi limbah keju oleh Kluyveromyces marxianus secara kontinyu dan steady state ditunjukkan pada persamaan (14); (19) dan (24). Simulasi proses fermentasi tersebut dilakukan dengan memvariasikan hydraulic retention time (HRT) dan konsentrasi substrat pada aliran masuk fermenter.

Hasil simulasi steady state ditunjukkan pada Gambar 4 - 7. Dari gambar tersebut dapat dilihat bahwa semakin besar hydraulic retention time maka konsentrasi substrat sisa akan semakin kecil. Penurunan konsentrasi substrat sisa ini terjadi karena konsumsi substrat yang meningkat untuk pertumbuhan sel dan pembentukan produk. Oleh sebab itu pada gambar 4. dan 6 konsentrasi sel dan produk meningkat dengan semakin besarnya harga hydraulic retention time.

Dari Gambar 5 terlihat bahwa konsentrasi substrat pada aliran masuk tidak mempengaruhi konsentrasi substrat sisa yang terdapat pada fermenter. Hal ini nampak dari persamaan (14) bahwa konsentrasi susbtrat sisa hanya dipengaruhi oleh hydraulic retention time. Namun kenaikan konsentrasi substrat di aliran masuk menyebabkan peningkatan konsentrasi sel dan etanol serta produktifitas etanol yang dihasilkan di fermenter.

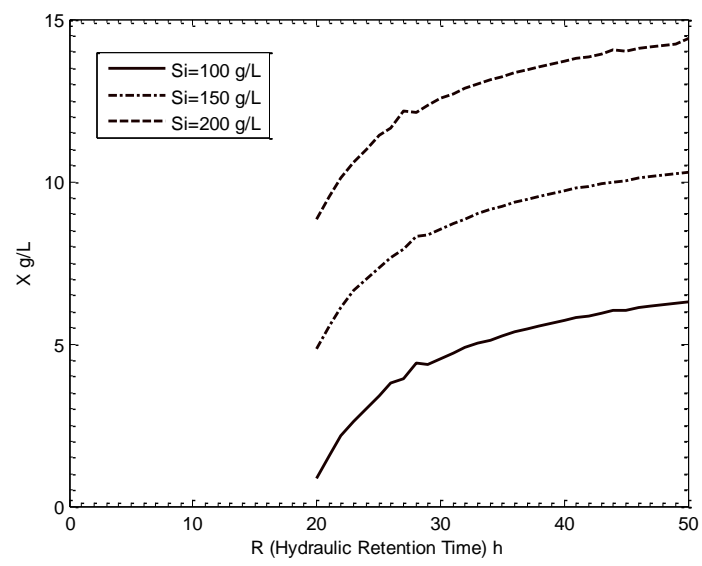

Gambar 4. Pengaruh hydraulic retention time dan konsentrasi substrat aliran masuk terhadap konsentrasi sel dalam fermenter.

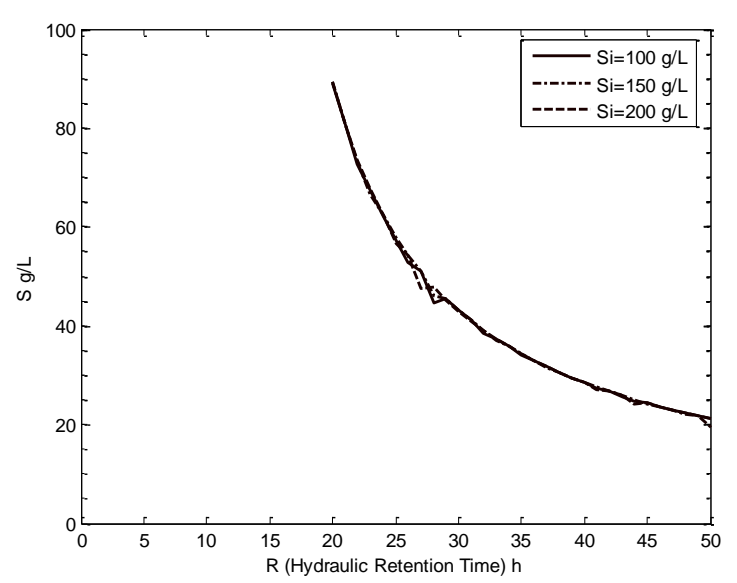

Gambar 5. Pengaruh hydraulic retention time dan konsentrasi substrat aliran masuk terhadap konsentrasi substrat dalam fermenter

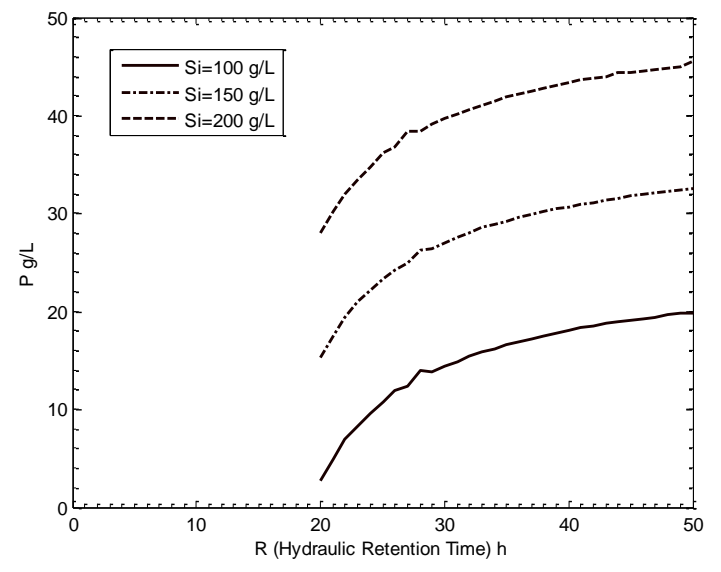

Gambar 6. Pengaruh hydraulic retention time dan konsentrasi substrat aliran masuk terhadap konsentrasi etanol dalam fermenter

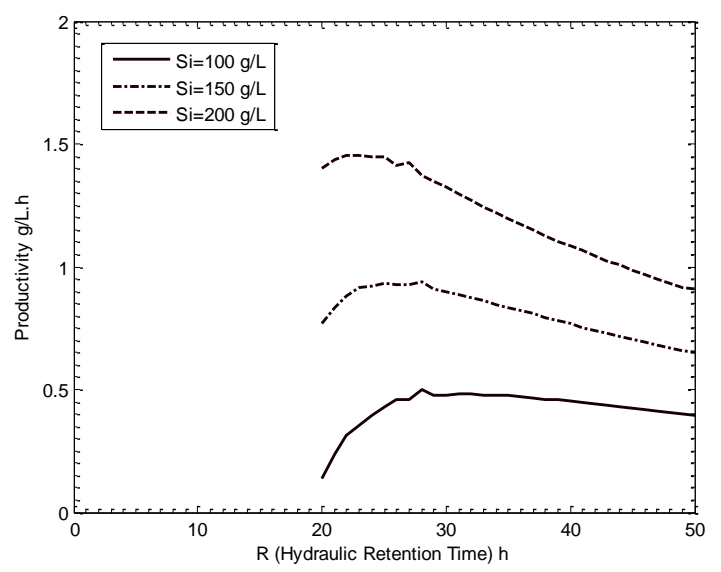

Gambar 7. Pengaruh hydraulic retention time dan konsentrasi substrat aliran masuk terhadap produktifitas etanol dalam fermenter 


\section{Kesimpulan}

Pada penelitian ini telah dilakukan kajian kritis terhadap proses fermentasi limbah keju dengan mengaplikasikan konsep neraca massa pada fermenter kontinyu. Pada kondisi steady state, proses fermentasi limbah keju menjadi bioetanol dipengaruhi oleh hydraulic retention time $(\mathrm{R})$. Pada kondisi steady state tersebut diperoleh harga $\mathrm{R}$ optimum sebesar 25 jam didasarkan pada produktifitas etanol yang tinggi. Harga R optimum ini sangat berguna dalam desain peralatan proses karena menentukan ukuran fermenter. Semakin besar harga R, semakin besar pula volume fermenter. Namun demikian semakin besar volume fermenter akan semakin besar pula biaya investasinya.

\section{Ucapan Terima Kasih}

Penulis mengucapkan terima kasih kepada Universitas Surabaya yang telah mendanai penelitian ini.

\section{Daftar Pustaka}

[1] Dochain D., Bioprocess Control, Wiley, 2008.

[2] Dunn, I.J., Heinzle, E., Ingham, J., Přenosil, J.E., Biological Reaction Engineering, Wiley-VCH, 2003.

[3] Ghaly, A.E., Taweel, A.A., Kinetic Modelling of Bacth Production of Ethanol from Cheese Whey, Biomass and Bioenergy, 6( 6), (1994) 465.

[4] Ghaly, A.E., Taweel, A.A, Kinetic Modelling of Continuous Production of Ethanol From Cheese Whey, Biomass and Bioenergy, 12(6), (1997) 461.

[5] Kargi, F., Ozmihci, S., Utilization of Cheese whey Powder (CWP) for Ethanol Fermentations: Effect of Operating Parameters, Enzyme and Microbial Technology, 38 (2006) 711.

[6] Kargi, F., Ozmihci, S., Continuous Ethanol Fermentation of Cheese Whey Powder Solution: Effects of Hydraulic Residence Time, Bioprocess Biosyst Eng., 30, (2007) 79.

[7] Zafar S., Owais M., Ethanol Production from Crude Whey by Kluyveromyces Marxianus, Biochemical Engineering, 27, (2005) 295. 